\title{
PENENTUAN PRIORITAS FAKTOR YANG MEMPENGARUHI KUALITAS WEBSITE UNIKA DE LA SALLE MANADO DENGAN METODE ANALYTICAL HIERARCHY PROCESS
}

\author{
Junaidy B. Sanger \\ Program Studi Teknik Informatika, Fakultas Teknik, Unika De La Salle, Manado \\ Kairagi 1 Kombos Manado \\ E-mail: jsanger@unikadelasalle.ac.id
}

\begin{abstract}
Unika De La Salle Manado is one of the university in Indonesia who have been using internet technology to support variety of activities such as teaching and learning, administration and other supporting activities. One of service that was established by this university is the university's website. The quality of website assessed by human perception which is very subjective because it involves many variables in the process of decision making. Evaluation of the level of interest of these factors are important to understand. Analytical Hierarchy Process (AHP) is a method to evaluate various attributes in the decision. The objectives of this study was to determine factors that affect Unika De La Salle Manado website users using AHP method. The result showed there were four main criteria ranked by priority such as system quality, information quality, service quality, and attractiveness with each eigen values of $0.3665,0.2323,0.2054$, and 0.1958. Overall on the alternative choice enjoyment got the highest eigen values of 0.5049 and the lowest is an alternative currency with eigen values of 0.0942. This research is expected to provide an overview on the factors of the quality of the website in order to increase the quality of Unika De La Salle Manado website and can be made for decision making to related parties.
\end{abstract}

Keywords: internet, quality of website, analytical hierarchy process

\section{PENDAHULUAN}

\section{Latar Belakang}

Perkembangan teknologi informasi dan komunikasi saat ini telah sampai pada tingkat yang memungkinkan para pengguna, dalam hal ini adalah manusia untuk melakukan pekerjaannya secara efektif dan efisien tanpa adanya kendala batas seperti jarak dan waktu. Penyebarluasan informasi juga menjadi salah satu suatu aspek yang sangat dipengaruhi oleh perkembangan teknologi tersebut. Berbagai macam layanan telah dikembangkan sehingga memungkinkan manusia untuk melakukan komunikasi kapan saja dan dimana saja dengan biaya yang jauh lebih murah dari biasanya. Teknologi internet salah satunya yang telah memungkinkan kita untuk bisa mengirimkan pesan dalam berbagai bentuk misalnya teks, gambar, suara, dan video bahkan bertatap muka langsung secara realtime.

Salah satu pengguna teknologi internet di dunia pendidikan adalah perguruan tinggi. Di Indonesia, hampir semua perguruan tinggi telah menggunakan teknologi ini dalam mendukung berbagai aktifitasnya. Unika De La Salle Manado adalah salah satu perguruan tinggi yang telah memanfaatkan teknologi internet untuk mendukung berbagai kegiatan, mulai dari belajar, mengajar, pembelajaran dan administrasi bahkan pada kegiatan-kegiatan pendukung lainnya. Salah satu layanan yang didirikan oleh Unika De La Salle Manado adalah website universitas yang beralamatkan di http://unikadelasalle.ac.id, dimana dari situs ini berbagai informasi seperti pengumuman, jadwal kegiatan akademik, pendaftaran, dan lain-lain disebarkan kepada masyarakat luas pada umumnya dan sivitas akademika Unika De La Salle Manado pada khususnya. Saat ini, website merupakan salah satu indikasi untuk membangun kredibilitas dan citra dari universitas. Oleh karna itu, universitas harus mampu menyajikan sebuah website yang berkualitas.

Pembangunan dan pengelolaan website ditentukan oleh kemampuan perancangan dokumen yang diterapkan, kompetensi pengelolaan dan pembaharuan data dan informasi, penerapan perangkat teknologi yang terkini, dan ketekunan dalam maintenance website secara teratur dan berkelanjutan. 
Menurut Lin (2010), ada empat aspek kriteria kualitas website yaitu: kualitas sistem, kualitas informasi, kualitas layanan dan daya tarik. Pengaruh aspek kriteria kualitas dari sebuah website merupakan sesuatu yang sangat penting karena dapat membantu pihak yang terkait dalam pengambilan keputusan untuk mengidentifikasi kebijakan yang terbaik untuk meningkatkan kualitas dari suatu website.

Kualitas website yang dinilai berdasarkan persepsi manusia merupakan suatu hal yang sangat subjektif yang melibatkan banyak faktor atau variabel dalam proses pengambilan keputusan (Saaty, 2008). Untuk itu, bagaimana mengevaluasi tingkat kepentingan dari faktor-faktor tersebut adalah sesuatu yang sangat penting untuk dipahami. Analytical Hierarchy Process (AHP) adalah sebuah metode untuk melakukan evaluasi berbagai atribut dalam pengambilan keputusan. AHP melakukan pemeringkatan terhadap masing-masing faktor yang mempengaruhi pengambilan keputusan, berdasarkan suatu struktur hierarki, memberikan pembobotan pada masing-masing elemen pada setiap level dari hierarki, menghitung prioritas terbobot (weighted priority), menampilkan urutan peringkat dari alternatif-alternatif yang dipertimbangkan (Marimin, 2008). AHP memiliki banyak keunggulan dalam menjelaskan proses pengambilan keputusan karena dapat digambarkan secara grafis, sehingga mudah dipahami oleh semua pihak yang terlibat dalam pengambilan keputusan. Dengan AHP, proses keputusan kompleks dapat diuraikan menjadi keputusan-keputusan lebih kecil yang dapat ditangani dengan mudah (Marimin dan Maghfiroh, 2010).

\section{Tujuan}

Adapun tujuan dari dilakukannya penelitian ini adalah untuk mengetahui prioritas dari faktor-faktor yang mempengaruhi kualitas website Unika De La Salle Manado dengan menggunakan metode AHP. Penelitian ini juga diharapkan dapat menjadi bahan masukan dalam pengambilan keputusan bagi pihak terkait sehingga kualitas website Unika $\mathrm{De}$ La Salle Manado dapat ditingkatkan secara berkesinambungan.

\section{Tinjauan Pustaka}

\section{Aspek Kriteria Website}

Ada empat aspek kriteria kualitas website yaitu sebagai berikut (Lin, 2010):

a. Kualitas Sistem

Kualitas sistem dapat didefinisikan sebagai kinerja dari suatu sistem dalam memberikan informasi untuk kepuasan pengguna dengan karakteristik yang terdiri dari:

- Accessbility yaitu berkaitan dengan tingkat sejauh mana suatu materi pembelajaran dapat diakses dengan usaha seminimal mungkin.

- Navigability yaitu memiliki sistem navigasi yang mudah untuk memperoleh informasi yang sesuai dengan kebutuhan.

- Response Time yaitu waktu respon yang cepat terhadap permintaan akan informasi.

- Learnibility yaitu kemudahan yang diperoleh pengguna dalam berinteraksi dengan website.

b. Kualitas Informasi

Kualitas informasi mengacu pada informasi yang disampaikan oleh penyedia layanan online.

Karakteristik dari kualitas informasi ini terdiri dari:

- Accuracy yaitu keakuratan yang mencerminkan persepsi bagi pengguna akan kebenaran informasi yang dibutuhkan.

- Currency yaitu kemutakhiran yang mengacu pada tingkat sejauh mana informasi tersebut menggambarkan kondisi terkini (update).

- Completeness yaitu kelengkapan sehingga pengguna memperoleh informasi yang dicari atau dibutuhkan dalam memahami materi pembelajaran.

- Format yang menggambarkan persepsi pengguna mengenai kesesuaian materi yang disampaikan dengan materi pembelajaran yang diterima pengguna.

c. Kualitas Layanan

Kualias layanan online berbeda dengan layanan secara tatap muka. Karakteristik dari kualitas layanan ini terdiri dari: 
- Realibility yang artinya kemampuan website untuk bisa diandalkan dalam memberikan layanan pada pengguna secara mandiri dan akurat sehingga pengguna dapat memperoleh solusi yang tepat terhadap informasi yang dibutuhkan.

- Responsiveness yaitu daya tanggap terhadap pengguna dalam memberikan pelayanan yang cepat.

- Trust didefinisikan sebagai kesediaan pengguna untuk menerima kekurangan dalam suatu interaksi online.

- Empathy yaitu perasaan empati yang berkaitan dengan perhatian secara individu dimana kebutuhan pengguna dapat dipahami sehingga pengguna puas dengan apa yang diperoleh.

d. Daya Tarik.

Daya tarik secara visual mengacu pada tingkat keyakinan pengguna bahwa halaman website tersebut menyenangkan untuk dibaca dan enak untuk dilihat. Karakteristik dari daya tarik ini terdiri dari:

- Multimedia Capability yaitu kemampuan multimedia yang mengacu pada perangkat-perangkat multimedia seperti teks, grafis, video clip, audio clip dan animasi, agar dapat menampilkan informasi sedemikian rupa sehingga mendorong rasa suka pengguna terhadap pemakaian website.

- Webpage Design yaitu desain halaman web yang mengacu pada desain yang bagus dan menarik serta tampilan yang tertata baik dari suatu website.

- Course Design yaitu desain pembelajaran yang mengacu pada desain yang sesuai skenario pembelajaran online.

- Enjoyment yaitu kesenangan atau kenyamanan yang mengacu pada sejauh mana pengguna senang dan puas ketika menggunakan website.

\section{Analytical Hierarcy Process (AHP)}

Metode Analytical Hierarcy Process (AHP) merupakan salah satu metode yang dapat digunakan dalam pengambilan keputusan dengan memperhatikan faktor-faktor persepsi, prefensi, pengalaman dan intuisi. AHP menggabungkan penilaian-penilaian dan nilai-nilai pribadi ke dalam satu cara yang logis (Marimin dan Maghfiroh, 2010). Prinsip kerja AHP adalah penyederhanaan suatu persoalan yang kompleks yang tidak terstruktur, strategik, dan dinamik menjadi sebuah bagian-bagian dan tertata dalam suatu hierarki. Tingkat kepentingan setiap variabel diberi nilai numerik, secara subjektif tentang arti penting variabel tersebut dan secara relatif dibandingkan dengan variabel yang lain. Dari berbagai pertimbangan kemudian dilakukan sintesa untuk menetapkan variabel yang memiliki prioritas tinggi dan berperan untuk mempengaruhi hasil pada sistem tersebut (Marimin dan Maghfiroh, 2010).

Terdapat 3 (tiga) prinsip dalam memecahkan persoalan dengan analisis logis eksplisit, yaitu penyusunan hierarki, penetapan prioritas, dan konsistensi logis. Model AHP ini menggunakan persepsi manusia yang dianggap expert dalam arti kata mengerti benar dengan permasalahan yang diajukan atau memiliki kepentingan dengan permasalahan. Adapun tahapan dalam perhitungan menggunakan metode AHP adalah sebagai berikut:

1. Mendefinisikan struktur hierarki masalah yang akan dipecahkan

2. Memberikan pembobotan elemen-elemen pada setiap level dan hierarki

3. Menghitung prioritas terbobot

4. Menampilkan urutan/peringkat dari alternatif-alternatif yang dipertimbangkan

5. Menghitung Consistency Ratio

\section{Penelitian Terkait}

Penelitian yang berkaitan dengan penentuan faktor yang mempengaruhi kualitas website juga telah dilakukan. Penelitian sebelumnya yang telah dilakukan oleh Lin (2010), yaitu mengembangkan model evaluasi fuzzy AHP yang memprioritaskan bobot relatif faktor kualitas website. Dalam penelitian tersebut dilakukan review terhadap literatur tentang kualitas website dan hasilnya diperoleh 4 (empat) kriteria dan 16 (enam belas) sub kriteria (alternatif) yang digunakan untuk mengukur kualitas website. Kemudian Rani dan Sakthivel (2015) telah melakukan suatu kajian mengenai penerapan AHP pada lingkungan berbasis web seperti pemilihan layanan web, pengembangan platform web, pemilihan website untuk iklan online dan perbankan. 


\section{Metode Penelitian}

Penelitian ini dilakukan dengan menggunakan metode Analytical Hierarchy Process (AHP) untuk mengetahui bagaimana menentukan apa sajakah faktor yang berpengaruh dan paling berpengaruh terhadap kualitas website Unika De La Salle Manado.

Kriteria utama untuk membuat keputusan terbagi atas empat, yaitu kualitas sistem, kualitas informasi, kualitas layanan dan daya tarik, beserta dengan subkriteria yang terkait dengan masing-masing kriteria tersebut. Menurut Lin (2010), kualitas sistem, kualitas informasi, kualitas layanan, dan daya tarik, masing-masing terdiri atas empat subkriteria, yaitu: Accessbility, Navigability, Response time, Learnibility; Accuracy, Currency, Completeness, Format; Reliability, Responsiveness, Trust, Empathy; Multimedia capability, Webpage design, Course design, Enjoyment.

Dalam penelitian ini, website Unika De La Salle Manado dijadikan sebagai Goal; kualitas sistem (website), kualitas informasi, kualitas layanan, dan daya tarik sebagai Kriteria; dan subkriteria dari masing-masing kriteria dijadikan sebagai Alternatif. Hierarki faktor-faktor yang mempengaruhi kualitas website Unika De La Salle Manado dapat dilihat pada Gambar 1.

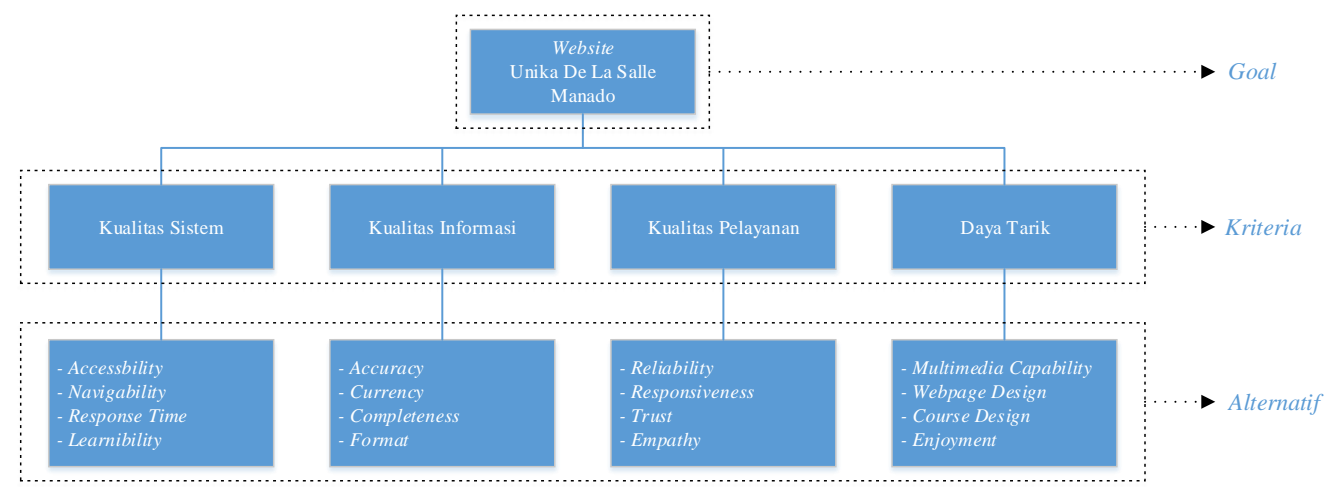

Gambar 1. Hierarki faktor-faktor yang mempengaruhi kualitas website

Perhitungan data kuesioner untuk mendapatkan analisis AHP yaitu dengan menjumlahkan hasil ratarata pilihan responden sesuai dengan kriteria dan alternatif dengan menggunakan formula sebagai berikut:

$\mathrm{A}_{\mathrm{w}}=\sqrt{a 1 \times a 2 \times a 3 x \ldots x a n}$

dimana:

$$
\begin{aligned}
\mathrm{A}_{\mathrm{w}} & =\text { Penilaian gabungan } \\
\mathrm{a} 1 & =\text { Penilaian responden ke-1 } \\
\mathrm{n} & =\text { Banyaknya responden }
\end{aligned}
$$

Setelah itu, hasil perhitungan geometri yang diperoleh dikalikan secara matriks sampai dengan iterasi ketiga untuk mendapatkan nilai eigen pada masing-masing kriteria dan alternatif. Contoh format matrik perbandingan berpasangan dapat dilihat pada Tabel 1 .

\begin{tabular}{|c|c|c|c|c|}
\hline C & A1 & A2 & A3 & A4 \\
\hline $\mathbf{A 1}$ & $\mathrm{a}_{11}$ & $\mathrm{a}_{12}$ & $\ldots$ & $\mathrm{a}_{14}$ \\
\hline $\mathbf{A 2}$ & $\mathrm{a}_{21}$ & $\mathrm{a}_{22}$ & $\ldots$ & $\mathrm{a}_{24}$ \\
\hline $\mathbf{A 3}$ & $\ldots$ & $\ldots$ & $\mathrm{a}_{33}$ & $\ldots$ \\
\hline $\mathbf{A 4}$ & $\mathrm{a}_{41}$ & $\mathrm{a}_{42}$ & $\ldots$ & $\mathrm{a}_{44}$ \\
\hline
\end{tabular}

Tabel 1. Contoh matrik perbandingan berpasangan

Perhitungan matrik ini diperoleh dari data kuesioner dimana kuesioner yang disebarkan tersebut menggunakan pola penilaian kriteria berdasarkan perbandingan berpasangan yang dapat dilihat pada 
Tabel 2. Setelah nilai eigen diperoleh maka selanjutnya dilakukan tahapan pemberian peringkat kepada kriteria dan alternatif. Setelah itu, nilai konsistensi logis atau Consistency Ratio (CR) dihitung. Dalam menghitung nilai konsistensi logis perlu diperhatikan mengenai suatu tingkat konsistensi tertentu yang sangat diperlukan dalam penentuan prioritas. Menurut Marimin (2008), konsistensi atau tidaknya suatu penilaian ditunjukkan oleh besarnya nilai $\mathrm{CR}$. Apabila $\mathrm{CR} \leq 10 \%$, maka matriks dianggap cukup konsisten, $10 \%<\mathrm{CR} \leq 15 \%$, matriks dianggap agak konsisten, sedangkan $\mathrm{CR}>15 \%$ matriks perbandingan berpasangan tersebut dianggap tidaklah konsisten. Untuk memperoleh nilai CR, terlebih dahulu harus dihitung nilai dari Consistency Index (CI) dengan menggunakan formula di bawah ini:

$\mathrm{CI}=\frac{(\lambda \max -n)}{(n-1)}$

dimana:

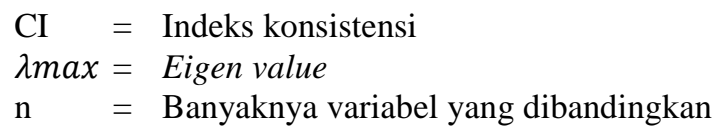

\begin{tabular}{|c|c|}
\hline Nilai & Keterangan \\
\hline 1 & A sama penting dengan B (equal importance) \\
\hline 3 & $\begin{array}{l}\text { A sedikit lebih penting dari B (moderate importance of one over } \\
\text { another) }\end{array}$ \\
\hline 5 & A jelas lebih penting dari B (strong or essential importance) \\
\hline 7 & $\begin{array}{l}\text { A sangat jelas lebih penting dari B (very strong or demonstrated } \\
\text { importance) }\end{array}$ \\
\hline 9 & Mutlak lebih penting dari B (extreme importance) \\
\hline $2,4,6,8$ & $\begin{array}{l}\text { Apabila ragu-ragu antara dua nilai yang berdekatan (intermediate } \\
\text { values reciprocals for inverse comparison) }\end{array}$ \\
\hline Reciprocal & $\begin{array}{l}\text { Jika elemen I memiliki salah satu angka di atas ketika } \\
\text { dibandingkan elemen } \mathrm{j} \text {, maka j memiliki nilai kebalikannya ketika } \\
\text { dibanding elemen } \mathrm{i}\end{array}$ \\
\hline
\end{tabular}

Tabel 2. Penilaian kriteria berdasarkan skala perbandingan berpasangan

Apabila CI bernilai 0 (nol), berarti bukan matrik konsisten. Batas ketidakkonsistensi diukur dengan menggunakan $\mathrm{CR}$, yakni perbandingan indeks konsistensi dengan nilai pembangkit random atau Random Index (RI). Nilai RI dari skala 1 sampai 10 dapat dilihat pada Tabel 3. Nilai ini bergantung pada ordo matrik n. Dengan demikian, CR dapat diukur dengan menggunakan formula sebagai berikut:

$\mathrm{CR}=\frac{\mathrm{CI}}{\mathrm{RI}}$

dimana:

$\mathrm{CR}=$ Consistency Ratio $; \mathrm{RI}=$ Random Index, sesuai dengan ordo matriks yang digunakan .

\begin{tabular}{llllll}
\hline $\mathbf{N}$ & $\mathbf{1}$ & $\mathbf{2}$ & $\mathbf{3}$ & $\mathbf{4}$ & $\mathbf{5}$ \\
\hline $\mathbf{R I}$ & 0,00 & 0,00 & 0,58 & 0,90 & 1,12 \\
\hline $\mathbf{N}$ & $\mathbf{6}$ & $\mathbf{7}$ & $\mathbf{8}$ & $\mathbf{9}$ & $\mathbf{1 0}$ \\
\hline $\mathbf{R I}$ & 1,24 & 1,32 & 1,41 & 1,45 & 1,49 \\
\hline
\end{tabular}

Tabel 3. Nilai index random

\section{PEMBAHASAN}

Bagian ini menjelaskan mengenai hasil analisis dan pembahasan penelitian dari metode Analytical Hierarchy Process (AHP) untuk penentuan faktor yang berpengaruh pada pengguna website Unika De 
La Salle Manado. Hasil perhitungan kuesioner untuk kriteria utama dengan menggunakan metode AHP setelah dilakukan penyebaran dapat dilihat pada Tabel 4.

\begin{tabular}{|c|c|}
\hline Kriteria utama & Nilai eigen \\
\hline (1) Kualitas Sistem & 0.3665 \\
\hline (2) Kualitas Informasi & 0.2323 \\
\hline (3) Kualitas Layanan & 0.2054 \\
\hline (4) Daya Tarik & 0.1958 \\
\hline
\end{tabular}

Tabel 4. Nilai eigen kriteria utama

\begin{tabular}{|c|c|}
\hline Alternatif & Nilai Eigen \\
\hline (1.1) Accessbility & 0.3080 \\
\hline (1.2) Navigability & 0.1022 \\
\hline (1.3) Response time & 0.1556 \\
\hline (1.4) Learnibility & 0.4342 \\
\hline (2.1) Accuracy & 0.3069 \\
\hline (2.2) Currency & 0.0942 \\
\hline (2.3) Completeness & 0.4095 \\
\hline (2.4) Format & 0.1894 \\
\hline (3.1) Reliability & 0.1501 \\
\hline (3.2) Responsiveness & 0.3406 \\
\hline (3.3) Trust & 0.1204 \\
\hline (3.4) Emphaty & 0.3889 \\
\hline (4.1) Multimedia capability & 0.1362 \\
\hline (4.2) Webpage design & 0.2579 \\
\hline (4.3) Course design & 0.1011 \\
\hline (4.4) Enjoyment & 0.5049 \\
\hline Tabel 5. Nilai eigen alternatif
\end{tabular}

Tabel 5. Nilai eigen alternatif

Pilihan dari kriteria utama yang memperoleh nilai tertinggi adalah kualitas sistem dengan nilai 0.3665 , pilihan kedua adalah kualitas informasi dengan nilai 0.2323 , pilihan ketiga adalah kualitas layanan dengan nilai 0.2054 , dan dengan nilai 0.1958 sebagai pilihan terakhir adalah daya tarik. Untuk penilaian pilihan alternatif pengguna website Unika De La Salle Manado ditampilkan pada Tabel 5. Hasil penilaian alternatif yang tertinggi adalah enjoyment dengan nilai eigen yang dihasilkan sebesar 0.5049 dan yang terendah dengan nilai eigen yang dihasilkan sebesar 0.0942 adalah currency. Peringkat faktor yang berpengaruh pada website Unika De La Salle Manado dapat dilihat pada Tabel 6. Berdasarkan Tabel 6, nilai eigen tertinggi untuk prioritas kriteria utama terdapat pada kualitas sistem dengan nilai 0.3665 , peringkat kedua adalah kualitas informasi dengan nilai 0.2323 , peringkat ketiga adalah kualitas layanan dengan nilai 0.2054 dan peringkat terakhir dengan nilai eigen 0.1958 adalah daya tarik. Untuk pilihan alternatif, learnibility menjadi peringkat pertama pada kualitas sistem dengan nilai eigen 0.4342; completeness menjadi peringkat pertama pada kualitas informasi dengan nilai eigen 0.4095; emphaty menjadi peringkat pertama pada kualitas layanan dengan nilai eigen 0.3889; dan enjoyment menjadi peringkat pertama pada daya tarik dengan nilai eigen 0.5049. 


\begin{tabular}{|c|c|c|c|}
\hline Kriteria utama & Alternatif & Nilai eigen & Peringkat \\
\hline \multirow[t]{5}{*}{ (1) } & & 0.3665 & 1 \\
\hline & $(1.1)$ & 0.3080 & 2 \\
\hline & $(1.2)$ & 0.1022 & 4 \\
\hline & (1.3) & 0.1556 & 3 \\
\hline & (1.4) & 0.4342 & 1 \\
\hline \multirow[t]{5}{*}{ (2) } & & 0.2323 & 2 \\
\hline & $(2.1)$ & 0.3069 & 2 \\
\hline & $(2.2)$ & 0.0942 & 4 \\
\hline & $(2.3)$ & 0.4095 & 1 \\
\hline & $(2.4)$ & 0.1894 & 3 \\
\hline \multirow[t]{5}{*}{ (3) } & & 0.2054 & 3 \\
\hline & $(3.1)$ & 0.1501 & 3 \\
\hline & (3.2) & 0.3406 & 2 \\
\hline & $(3.3)$ & 0.1204 & 4 \\
\hline & (3.4) & 0.3889 & 1 \\
\hline \multirow[t]{5}{*}{ (4) } & & 0.1958 & 4 \\
\hline & $(4.1)$ & 0.1362 & 3 \\
\hline & $(4.2)$ & 0.2579 & 2 \\
\hline & $(4.3)$ & 0.1011 & 4 \\
\hline & $(4.4)$ & 0.5049 & 1 \\
\hline
\end{tabular}

Tabel 6. Nilai peringkat alternatif faktor yang berpengaruh pada website

Hasil perhitungan nilai Consistency Ratio (CR) untuk setiap kriteria utama, yaitu kualitas sistem, kualitas informasi, kualitas layanan, dan daya tarik dapat dilihat pada Tabel 7. Dari Tabel 7 dan merujuk pada syarat nilai CR (Marimin 2008) dapat dilihat bahwa kriteria daya tarik agak konsisten dengan nilai CR sebesar 0.1191 dan kriteria lainnya, yaitu kualitas sistem, kualitas informasi dan kualitas layanan cukup konsisten dengan nilai CR masing-masing 0.0288, 0.0771, dan 0.0291.

\begin{tabular}{|c|l|c|}
\hline No & \multicolumn{1}{|c|}{ Kriteria } & Nilai CR \\
\hline 1 & Kualitas Sistem & 0.0288 \\
\hline 2 & Kualitas Informasi & 0.0771 \\
\hline 3 & Kualitas Layanan & 0.0291 \\
\hline 4 & Daya Tarik & 0.1191 \\
\hline
\end{tabular}

Tabel 7. Nilai perhitungan Consistency Ratio

\section{KESIMPULAN}

Penelitian ini telah berhasil menentukan prioritas dari faktor-faktor yang mempengaruhi kualitas website Unika De La Salle Manado dengan menggunakan metode AHP (Analytical Hierarchy Process). Pada kriteria utama, kualitas sistem sebagai peringkat pertama dengan nilai eigen yang dihasilkan sebesar 0.3665 , kualitas informasi sebagai peringkat kedua dengan nilai eigen yang dihasilkan sebesar 0.2323 , kualitas layanan sebagai peringkat ketiga dengan nilai eigen yang dihasilkan sebesar 0.2054 , dan daya tarik dengan nilai eigen yang dihasilkan sebesar 0.1958 sebagai peringkat terakhir. 
Alternatif enjoyment dengan nilai eigen 0.5049 mendapatkan peringkat pertama pada penilaian alternatif keseluruhan dan alternatif currency merupakan alternatif terendah dengan nilai eigen 0.0942 . Pada kriteria kualitas sistem, pilihan alternatif learnibility sebagai peringkat pertama dengan nilai eigen sebesar 0.4342 , accessbility sebagai peringkat kedua dengan nilai eigen sebesar 0.3080, response time sebagai peringkat ketiga dengan nilai eigen sebesar 0.1556, dan navigability dengan nilai eigen sebesar 0.1022 sebagai peringkat terakhir. Pada kriteria kualitas informasi, completeness sebagai peringkat pertama dengan nilai eigen 0.4095 , accuracy sebagai peringkat kedua dengan nilai eigen 0.3069 , format sebagai peringkat ketiga dengan nilai eigen sebesar 0.1894, dan currency dengan nilai eigen sebesar 0.0942 sebagai peringkat terakhir. Pada kriteria kualitas layanan, emphaty sebagai peringkat pertama dengan nilai eigen sebesar 0.3889 , responsiveness sebagai peringkat kedua dengan nilai eigen sebesar 0.3406 , reliability sebagai peringkat ketiga dengan nilai eigen sebesar 0.1501 , dan trust dengan nilai eigen sebesar 0.1204 sebagai peringkat terakhir. Pada pilihan kriteria daya tarik, enjoyment sebagai peringkat pertama dengan nilai eigen sebesar 0.5049 , webpage design sebagai peringkat kedua dengan nilai eigen sebesar 0.2579 , multimedia sebagai peringkat ketiga dengan nilai eigen sebesar 0.1362 dan course design dengan nilai eigen sebesar 0.1011 sebagai peringkat terakhir. Adapun yang menjadi saran dalam penelitian ini yang berkaitan juga dengan hasil yang diperoleh untuk penelitian selanjutnya dapat dilakukan penambahan tingkat responden untuk lebih mendapatkan hasil yang lebih merata, dan faktor-faktor yang mendapatkan peringkat terbawah perlu diperhatikan kembali.

\section{DAFTAR PUSTAKA}

Lin, H.F. 2010. An Application of fuzzy AHP for evaluating course website quality. Elsevier Computer \& Education. 54(2010): 877-888.

Marimin., Maghfiroh, N. 2010. Aplikasi Teknik Pengambilan Keputusan dalam Manajemen Rantai Pasok. Bogor (ID): IPB Press.

Marimin. 2008. Teknik dan Aplikasi Pengambilan Keputusan Kriteria Majemuk. Jakarta (ID): Grasindo.

Rani, M.D.K., Sakthivel, S. 2015. Analytical Hierarchy Process - Study on its Applicability on Web Based Environment. International Journal of Software Engineering and Its Applications. 9(4): $37-46$.

Saaty, T.L. 2008. Decision making with the analytic hierarchy process. Int. J. Services Sciences. 1(1): 83-98. 